\title{
Thermodynamics and Mechanism of Silicon Reduction by Carbon in a Crucible Reaction
}

\section{VLADIMIR ALEXANDROVICH GRACHEV}

\author{
A.N. Frumkin Institute of Physical Chemistry and Electrochemistry RAS, \\ 31, Bldg 4, Leninsky prospect, 119071, Moscow, Russia. \\ ${ }^{*}$ Corresponding author E-mail: vagrachev@gmail.com \\ http://dx.doi.org/10.13005/ojc/320612
}

(Received: November 26, 2016; Accepted: December 13, 2016)

\begin{abstract}
In the paper, the author has represented a thermodynamic analysis of a crucible reaction, which takes place in crucible induction furnaces. The author has suggested a diagram of a crucible reaction that took into account partial pressure and activity of the components participating in the process. The author has defined more exactly what effect the elements usually present in cast iron $(\mathrm{Mn}, \mathrm{S}, \mathrm{P})$ and main alloying elements $(\mathrm{Cr}, \mathrm{Ni}, \mathrm{Al}, \mathrm{Cu})$ had on activity and equilibrium concentrations of carbon and silicon in cast iron. The electrochemical mechanism of a crucible reaction has been studied. The author has proved that electrical current had influence on the process. The obtained data allow improving the technology of cast iron induction melting.
\end{abstract}

Keywords: Cast iron melting, Electric induction furnace, Crucible reaction, Thermodynamics, Electrochemical mechanism of reaction.

\section{INTRODUCTION}

Metal melting is a complex physicalchemical process of a metal's simultaneous heating, melting, and overheating over melting temperature and interaction with the gas phase and the reaction products, which change from the metallic state to the oxide and form a slag. In foundry operations cast iron melting or the so-called secondary cast iron melting is carried out in coke and gas cupolas, induction-type and electric arc furnaces. Cast iron melting in a foundry conductor is increasingly done in electric induction furnaces ${ }^{1,2}$. While in Russia in
$2010,60 \%$ of all cast iron was smelted in cupola furnaces and $40 \%$ - in electric induction furnaces, by 2014 electric induction furnaces accounted for $60 \%$ of all cast iron produced and only $40 \%$ was produced in cupola furnaces.

\section{METHOD}

One of the most important aspects of cast iron melting in an induction furnace is the crucible reaction's process:

$<\mathrm{SiO}_{2}>+[2 \mathrm{C}]=[\mathrm{Si}]+\{2 \mathrm{CO}\}$ 
The equilibrium of this reaction, depending on the temperature, is described by the diagram of equilibrium values [Si] and [C] (it is also being called Oelsen - Roesch - Orths diagram) (Figure 1a). This diagram was made more precise by the $p_{\text {co }}$ value in Neumann and Dötsch research ${ }^{7}$. All the authors believed that $\mathrm{a}_{\mathrm{SiO} 2}$. However, can be assumed only in a completely new lining. A worn out, or in other words previously used, liner has $\mathrm{a}_{\mathrm{SiO} 2}$ content of $60-65 \%$, and accordingly, the value of changes. The migration of the point of intersection of the lines $\Delta \mathrm{G}-\mathrm{T}$ for $\mathrm{CO}$ and $\mathrm{SiO}_{2}$, when $\mathrm{aSiO}_{2}<1$ and $\mathrm{p}_{\mathrm{CO}}<1$, is shown in the Figure 2. With that, $p_{c o}<1$ may be significant for vacuum melting; under real conditions of induction melting, the $\mathrm{CO}$ pressure reaches 2.5 atm or more.

For the crucible reaction, the real values of $\mathrm{a}_{\mathrm{SiO} 2}$ decrease from 1 to 0.6 as the reaction proceeds. Real pressure values $p_{\text {co }}$ for industrial furnaces reach 3 atm. Figure 2 shows the change in pressure by height for various induction furnaces, calculated using the formula:

$$
P=\frac{2 \sigma}{r}+g h_{M} \cdot \rho_{M} \text {. }
$$

It is clear that for the initial period of $\mathrm{CO}$ formation, when the radius of its emerging bubble is insignificant, a substantial resistance to the proceeding of the crucible reaction is possible.

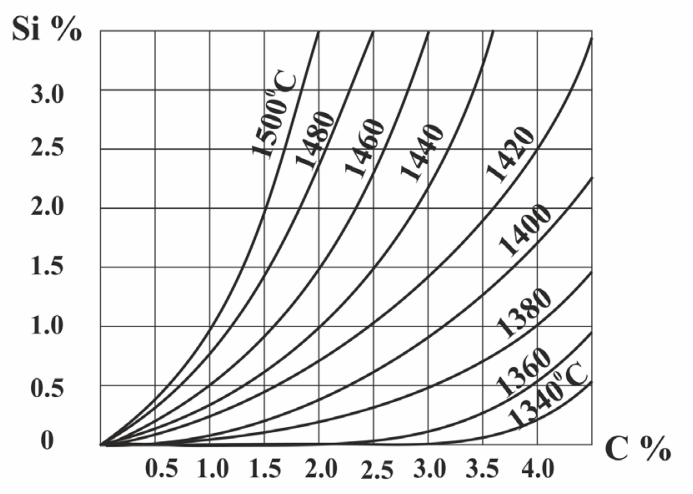

a
When analyzing Neumann and Dötsch's and our data, the equilibrium of the crucible reaction must be considered in the interval of pressure $p_{c o}$ from 1.5 to $3 \mathrm{~atm}$ and in the interval of activity $\mathrm{a}_{\mathrm{SiO} 2}$ from 0.6 to 1 . A refined diagram, based on the aforementioned assumption, is shown in Figure 3. It is clear, that for the bottom part of the crucible $\left(p_{c o}=3 \mathrm{~atm}\right)$, the probability of the crucible reaction proceeding is substantially lower than for the upper part $\left(p_{c o}=1.5 \mathrm{~atm}\right)$. Crucible reaction inhibition due to the decrease in $\mathrm{SiO}_{2}$ activity is also quite noticeable.

The update of the Oelsen - Roeseh Orths diagram, performed by Neumann and Dötsch, affected the activities $\mathrm{a}_{\mathrm{C}}$ and $\mathrm{a}_{\mathrm{Si}}$ with due account for their mutual influence (Figure 1b).

\section{RESULTS}

The author clarified the effect of elements usually present in cast iron (Mn, S, P), as well as the effect of main alloying elements $(\mathrm{Cr}, \mathrm{Ni}, \mathrm{Al}, \mathrm{Cu})$ on activity and equilibrium concentrations of carbon and silicon in cast iron.

The calculation, taking into account the influence coefficients $\varepsilon_{\mathrm{C}}{ }^{\mathrm{Mn}}, \varepsilon_{\mathrm{C}}{ }^{\mathrm{s}}$ and other, $\varepsilon_{\mathrm{C}}{ }^{\mathrm{j}}$ and $\varepsilon_{\mathrm{Si}}{ }^{j}$ according to Elliott ${ }^{3}$, allowed to calculate the corrections of the equilibrium values of $\mathrm{C}$ and $\mathrm{Si}$ (Table 1 and 2).

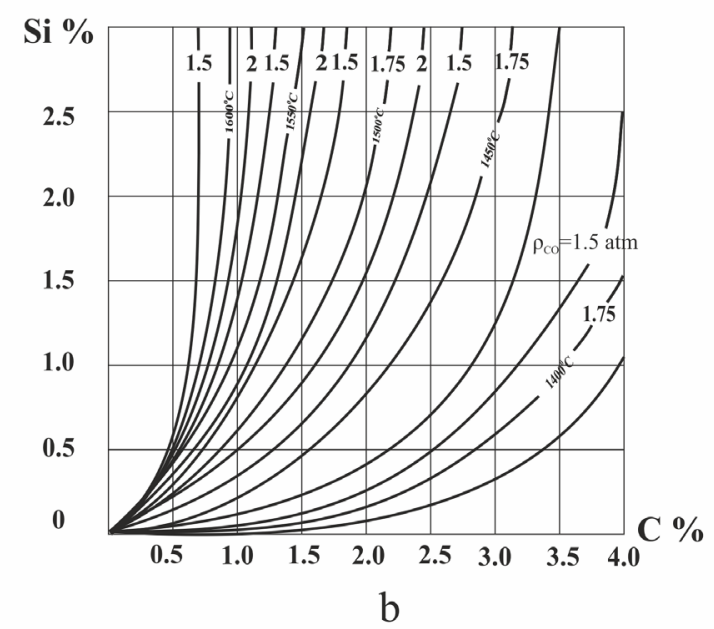

Fig. 1: Crucible reaction's equilibrium diagrams: a) Oelsen - Roesch - Orths; b) Neumann and Dötsch 
These data show that decrease in carbon activity due to presence of manganese in the cast iron sample is equivalent to a decrease in carbon concentration by $0.1 \%$. A positive change in carbon activity due to presence of sulfur and phosphorus in quantities that are natural for cast iron samples

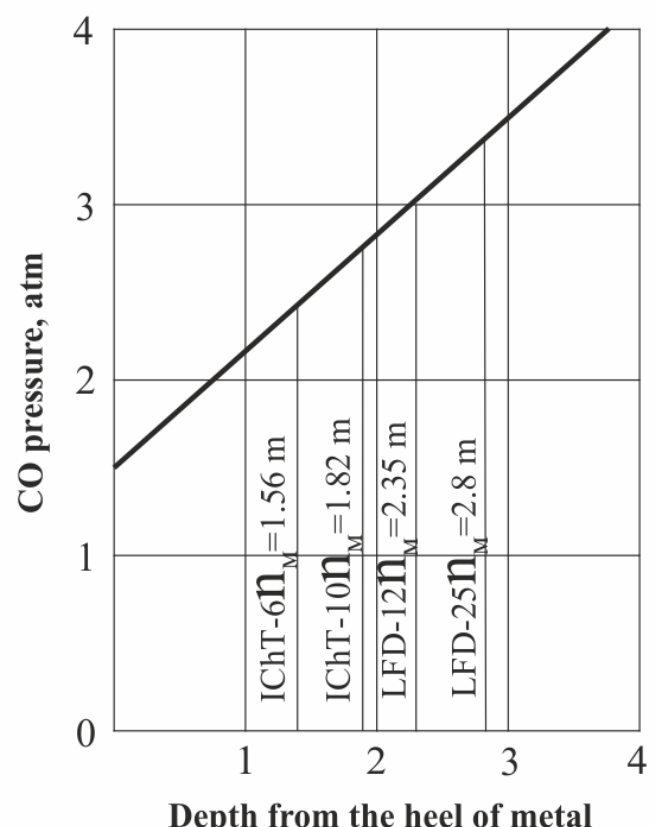

Fig. 2: CO pressure in industrial electric induction furnaces
$(0.1-0.15 \%)$ is equivalent to an increase in carbon content by $0.1 \%$.

Thereby, there is no need to update the Neumann and Dötsch diagram on the content of $\mathrm{Mn}, \mathrm{S}$ and $\mathrm{P}$ in gray cast irons.

The changes in concentration of Si (Table 2 ), equivalent to the change in activity, are so negligible $\left(\Delta \mathrm{Si}_{\mathrm{Mn}}+\Delta \mathrm{Si}_{\mathrm{S}}+\Delta \mathrm{S}_{\mathrm{ip}} \approx 0.1 \%\right)$ that there is also no need to take them into account, as this effect is equivalent to a change in equilibrium temperature by just $5^{\circ} \mathrm{C}$.

Alloying elements can have a substantial impact on the crucible reaction: a significant amount of $\mathrm{Cr}$ inhibits the crucible reaction; the reaction is accelerated by significant amounts of $\mathrm{Ni}, \mathrm{Cu}$, and especially Al (Table 1 and 2).

Figure 4 shows a nomogram designed for real conditions of melting, allowing precise measurement of the melting mode.

\section{DISCUSSION}

The research of the crucible reaction's mechanism was performed on $\mathrm{SiO}_{2}$ samples, which were sintered with boric acid and loaded into the molten cast iron in the induction furnace. By

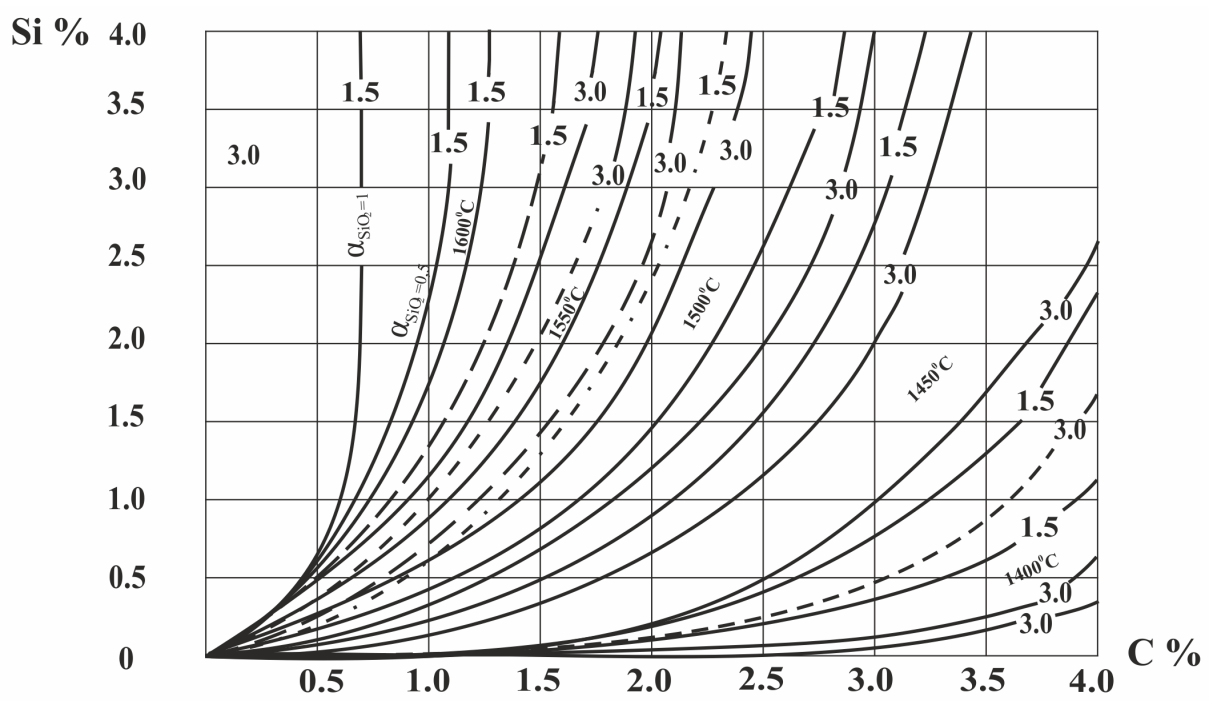

Fig. 3: Diagram with precised $a_{\text {sio2 }}$ and $p_{\text {co }}$ 
Table 1: Change in equilibrium concentration of carbon depending on the content of elements

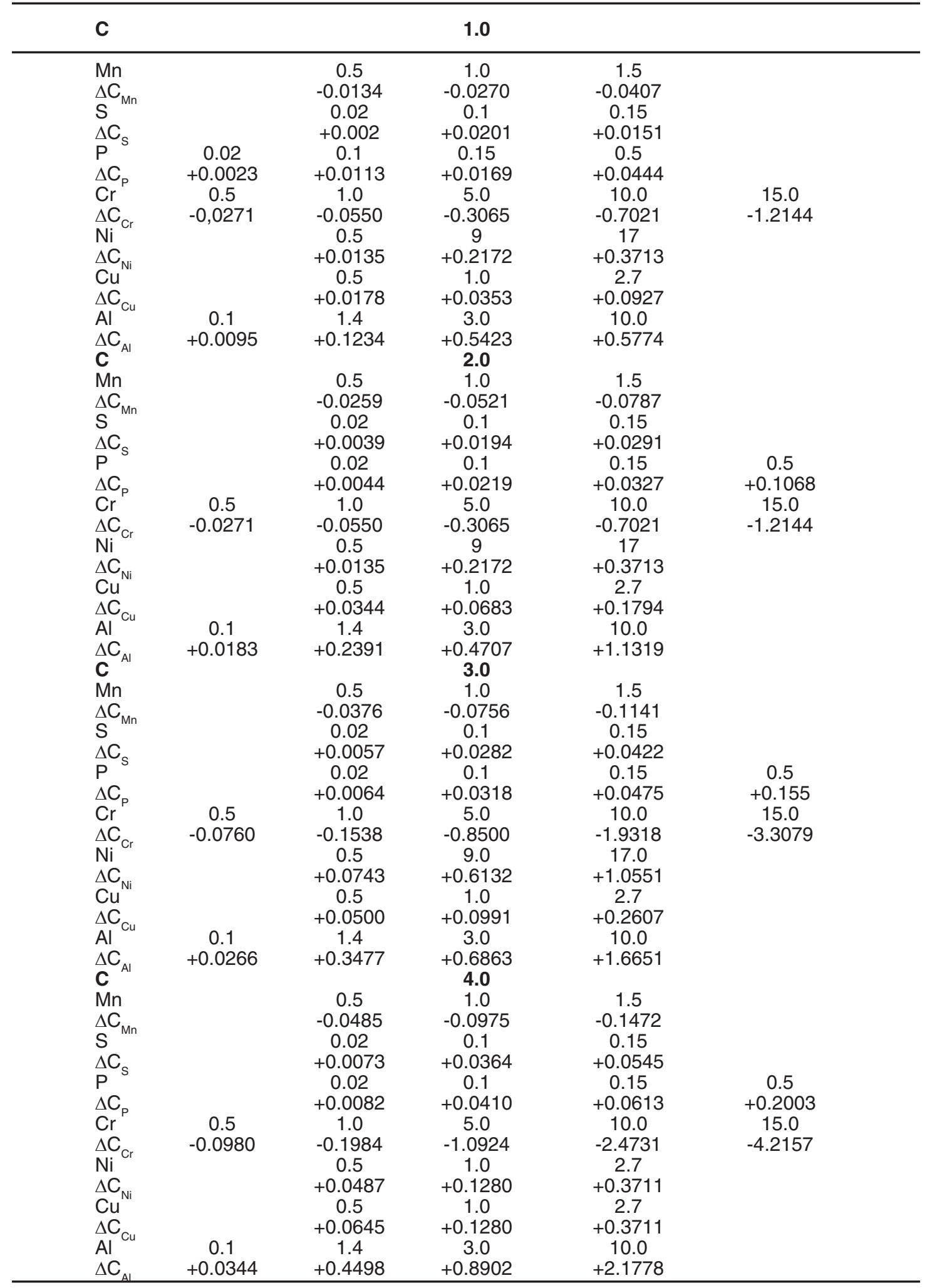


Table 2: Change in equilibrium concentration of silicon depending on the content of elements

\begin{tabular}{|c|c|c|c|c|}
\hline Si & & 0.5 & & \\
\hline $\mathrm{Mn}$ & 0.5 & 1.0 & 1.5 & \\
\hline$\Delta \mathrm{Si}$ & +0.0020 & +0.0059 & +0.0019 & \\
\hline & 0.02 & 0.1 & 0.15 & \\
\hline$\Delta \mathrm{Si}_{\mathrm{S}}$ & +0.0020 & +0.0066 & +0.0088 & \\
\hline $\mathrm{P}^{\mathrm{s}}$ & 0.02 & 0.1 & 0.15 & 0.5 \\
\hline$\Delta \mathrm{Si}_{\mathrm{p}}$ & +0.0020 & +0.0113 & +0.0181 & +0.0568 \\
\hline $\mathrm{Cr}^{\mathrm{P}}$ & 0.5 & 10.0 & 1.0 & 15.0 \\
\hline$\Delta \mathrm{Si}_{\mathrm{Cr}}$ & 0 & 0 & 0 & 0 \\
\hline $\mathrm{Ni}{ }^{\mathrm{Cr}}$ & 0.5 & 9.0 & 17.0 & \\
\hline$\Delta \mathrm{Si}_{\mathrm{Ni}}$ & +0.0022 & +0.0507 & +0.0925 & \\
\hline $\mathrm{Cu}{ }^{\mathrm{Ni}}$ & 0.5 & 1.0 & 2.7 & \\
\hline$\Delta \mathrm{Si}_{\mathrm{C}}$ & +0.0072 & +0.0217 & +0.0420 & \\
\hline $\mathrm{Al}$ & 0.1 & 1.4 & 3.0 & 10.0 \\
\hline$\Delta \mathrm{Si}_{\mathrm{Al}}$ & +0.0064 & +0.0847 & +0.1602 & +0.3497 \\
\hline $\mathrm{Mn}$ & 0.5 & 1.0 & 1.5 & \\
\hline$\Delta \mathrm{Si}_{\mathrm{in}}$ & +0.0031 & +0.0050 & +0.0072 & \\
\hline $\mathrm{S}$ & 0.02 & 0.1 & 0.15 & \\
\hline$\Delta \mathrm{Si}_{\mathrm{c}}$ & +0.0040 & +0.0131 & +0.0191 & \\
\hline $\mathrm{P}^{\mathrm{s}}$ & 0.02 & 0.1 & 0.15 & 0.5 \\
\hline$\Delta \mathrm{Si}_{\mathrm{p}}$ & +0.0040 & +0.0256 & +0.0345 & +0.1158 \\
\hline $\mathrm{Cr}$ & 0.5 & 1.0 & 10.0 & 15.0 \\
\hline$\Delta \mathrm{Si}_{\mathrm{cr}}$ & 0 & 0 & 0 & 0 \\
\hline $\mathrm{Ni}{ }^{\mathrm{Cr}}$ & 0.5 & 9.0 & 17.0 & \\
\hline$\Delta \mathrm{Si}_{\mathrm{Ni}}$ & +0.0044 & +0.0997 & +0.1831 & \\
\hline $\mathrm{Cu}$ & 0.5 & 1.0 & 2.7 & \\
\hline$\Delta \mathrm{Si}_{\mathrm{C}}$ & +0.0176 & +0.0307 & +0.0851 & \\
\hline $\mathrm{Al}$ & 0.1 & 1.4 & 3.0 & 10.0 \\
\hline$\Delta \mathrm{Si}_{\mathrm{Al}}$ & +0.0128 & +0.1664 & +0.3194 & +0.6977 \\
\hline $\mathrm{Si}^{\mathrm{Ai}}$ & & 2.0 & & \\
\hline $\mathrm{Mn}$ & 0.5 & 1.0 & 1.5 & \\
\hline$\Delta \mathrm{Si}_{\mathrm{in}}$ & +0.0069 & +0.0119 & +0.0371 & \\
\hline$S^{M n}$ & 0.02 & 0.1 & 0.15 & \\
\hline$\Delta \mathrm{Si}_{\mathrm{S}}$ & +0.0068 & +0.0261 & +0.0354 & \\
\hline $\mathrm{P}$ & 0.02 & 0.1 & 0.15 & 0.5 \\
\hline$\Delta \mathrm{Si}_{\mathrm{p}}$ & +0.0119 & +0.0460 & +0.0697 & +0.2287 \\
\hline $\mathrm{Cr}^{\mathrm{P}}$ & 0.5 & 1.0 & 5.0 & 10.0 \\
\hline$\Delta \mathrm{Si}_{\mathrm{Cr}}$ & 0 & 0 & 0 & 0 \\
\hline $\mathrm{Ni}{ }^{\mathrm{Cr}}$ & 0.5 & 9.0 & 17.0 & \\
\hline$\Delta S i_{N i}$ & +0.0123 & +0.2019 & +0.3626 & \\
\hline $\mathrm{Cu}{ }^{\mathrm{Ni}}$ & 0.5 & 1.0 & 2.7 & \\
\hline$\Delta \mathrm{Si}_{\mathrm{c}}$ & +0.0337 & +0.0646 & +0.1699 & \\
\hline $\mathrm{Al}{ }^{\mathrm{Cu}}$ & 0.1 & 1.4 & 3.0 & 10.0 \\
\hline$\Delta \mathrm{Si}_{\mathrm{Al}}$ & +0.0254 & +0.3321 & +0.6343 & +1.3889 \\
\hline $\mathrm{Si}$ & & 3.0 & & \\
\hline $\mathrm{Mn}$ & 0.5 & 1.0 & 1.5 & \\
\hline$\Delta \mathrm{Si}_{\mathrm{Mn}}$ & +0.0104 & +0.0162 & +0.0221 & \\
\hline$S^{\text {Min }}$ & 0.02 & 0.1 & 0.15 & \\
\hline$\Delta \mathrm{Si}_{\mathrm{S}}$ & +0.0161 & +0.0389 & +0.0558 & \\
\hline$P^{s}$ & 0.02 & 0.1 & 0.15 & 0.5 \\
\hline$\Delta \mathrm{Si}_{\mathrm{P}}$ & +010162 & +0.0686 & +0.1084 & +0.3390 \\
\hline $\mathrm{Cr}$ & 0.5 & 1.0 & 5.0 & 10.0 \\
\hline$\Delta \mathrm{Si}_{\mathrm{cr}}$ & 0 & 0 & 0 & 0 \\
\hline $\mathrm{Ni}{ }^{\mathrm{Ci}}$ & 0.5 & 9.0 & 17.0 & \\
\hline$\Delta \mathrm{Si}_{\mu}$ & +0.0174 & +0.2964 & +0.5372 & \\
\hline $\mathrm{Cu}{ }^{\mathrm{Ni}}$ & 0.5 & 1.0 & 2.7 & \\
\hline$\Delta S i$ & +0.0488 & +0.0920 & +0.2471 & \\
\hline $\mathrm{Al}{ }^{\mathrm{Cu}}$ & 0.1 & 1.4 & 3.0 & 10.0 \\
\hline$\Delta \mathrm{Si}_{\mathrm{AL}}$ & +0.0379 & +0.4941 & +0.9463 & +2.0743 \\
\hline
\end{tabular}


passing electrical currents of different intensities and polarities, it was found that the crucible reaction can be accelerated. The sample is one of the electrodes, the second electrode is metal. Since the passing of the electrical current had a noticeable impact on the crucible reaction, we suggest the presence of an electrolyte between the electrodes. Therefore, the crucible reaction's mechanism can be presented in the following way:

$$
\frac{\gamma}{2}<\mathrm{SiO}_{4}^{4-}>+\left[\gamma \mathrm{C}^{x+}\right]-n e=\frac{\gamma}{2}<\mathrm{Si}^{4+}>+\gamma\{\mathrm{CO}\}
$$

$$
\frac{\gamma}{2}<S i^{4+}>+n e=\frac{\gamma}{2}[S i]
$$

This mechanism should be considered very tentatively, as the structure of the highly siliceous layer is much more complex than the $\mathrm{SiO}_{4}^{4-}$ ionic melt.
The boundary layer of the quartz lining is composed of polyionic complexes of various complexities with inclusions of boric compounds and various impurities. The development of the capillary and other phenomena leads to decrease in $\mathrm{SiO}_{2}$ content to $60-70 \%$ in the boundary layer. Spent mass of the induction furnace's lining is composed of $70 \% \mathrm{SiO}_{2}, 4-8 \% \mathrm{Al}_{2} \mathrm{O}_{3}, 2-8 \% \mathrm{Fe}_{2} \mathrm{O}_{3}, 8-12 \% \mathrm{FeO}$, $1-2 \% \mathrm{CaO}, 0.8-1.6 \% \mathrm{MgO}, 0.4-1.5 \% \mathrm{~B}_{2} \mathrm{O}_{3}$, and $4-8 \%$ $\mathrm{MnO}$.

According to Zolotov ${ }^{8}$, spent lining is composed of $65.64 \% \mathrm{SiO}_{2}, 6.72 \% \mathrm{Al}_{2} \mathrm{O}_{3}, 4.9 \% \mathrm{Fe}_{2} \mathrm{O}_{3}$, $12.33 \% \mathrm{FeO}, 1.39 \% \mathrm{CaO}, 1.24 \% \mathrm{MgO}, 0.4 \% \mathrm{~B}_{2} \mathrm{O}_{3}$, $7.02 \% \mathrm{MnO}$, and $0.2 \% \mathrm{TiO}_{2}$.

According to the Esin - Masson theory ${ }^{4,5,6}$ the silicon-oxygen anions get polymerized:

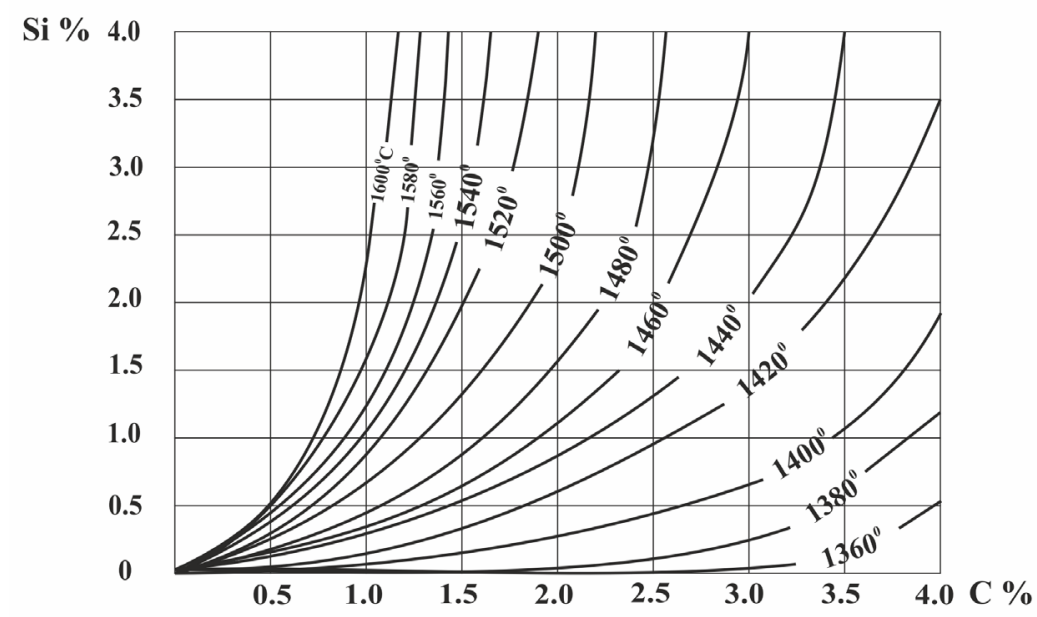

Fig. 4: V.A. Grachev's summary diagram for crucible reaction

\begin{tabular}{|c|c|c|c|c|c|c|c|}
\hline \multirow{2}{*}{$\begin{array}{l}\text { Mole fraction in the } \\
\text { slag composition }\end{array}$} & \multirow[b]{2}{*}{0.17} & \multicolumn{6}{|c|}{ Polymerization constant K-value } \\
\hline & & 1.0 & 2.0 & 5.0 & 10.0 & 20.0 & 50.0 \\
\hline $\mathrm{SiO}_{2}$ & 0.7163 & 0.7163 & 0.7163 & 0.7163 & 0.7163 & 0.7163 & 0.7163 \\
\hline $\mathrm{Si}_{2} \mathrm{O}_{4}^{4-}$ & 0.116 & 0.107 & 0.057 & 0.021 & 0.014 & 0.003 & 0.00042 \\
\hline $\mathrm{Si}_{1}^{2} \mathrm{O}_{3 i+1}^{2(i+1-c)-}$ & 0.034 & 0.0305 & 0.019 & 0.003 & 0.002 & 0.00016 & 0.000001 \\
\hline $\mathrm{Si}_{1} \mathrm{O}_{3 i+1}^{2(i+1)-}$ & 0.167 & 0.15 & 0.072 & 0.024 & 0.016 & 0.003 & 0.00043 \\
\hline $\mathrm{Si}_{1} \mathrm{O}_{3 i+1} 2(i+1)-$ & 0.137 & 0.114 & 0.068 & 0.022 & 0.019 & 0.0034 & 0.00044 \\
\hline $\begin{array}{l}\mathrm{Si}_{1} \mathrm{O}_{3 \mathrm{i}}{ }^{2 \mathrm{i}-} \text { and ions } \\
\text { at } \mathrm{c}>1\end{array}$ & 0.695 & 0.736 & 0.837 & 0.961 & 0.968 & 0.997 & 0.991 \\
\hline
\end{tabular}

Table 3: Distribution of silicon-oxygen anions at various values of polymerization constant 
$\mathrm{SiO}_{4}^{4-}+\mathrm{SiO}_{4}^{4-}=\mathrm{Si}_{2} \mathrm{O}_{7}^{6-}+\mathrm{O}^{2-}$

$\mathrm{SiO}_{4}^{4-}+\mathrm{SiO}_{7}^{6-}=\mathrm{Si}_{3} \mathrm{O}_{10}^{3-}+\mathrm{O}^{2-}$

These reactions are characterized by the polymerization constant $K$, and in general the silicon ions can be written as $S i_{i} O_{(3 i+1-c)}^{2(i+1-c)}$, and the polymerization reaction is as follows:

$$
S i_{i} O_{(3 i+1-c)}^{2(i+1-c)}+S i O_{4}^{4-}=S i_{i+1} O_{(3 i+1-c)}^{2(i+1-c)-}
$$

The calculations given by Esin for various values of the $\mathrm{SiO}_{2}$ mole fraction in the silicate $\mathrm{N}_{\mathrm{SiO} 2}$ have shown that even when $\mathrm{k}=0$, the melt

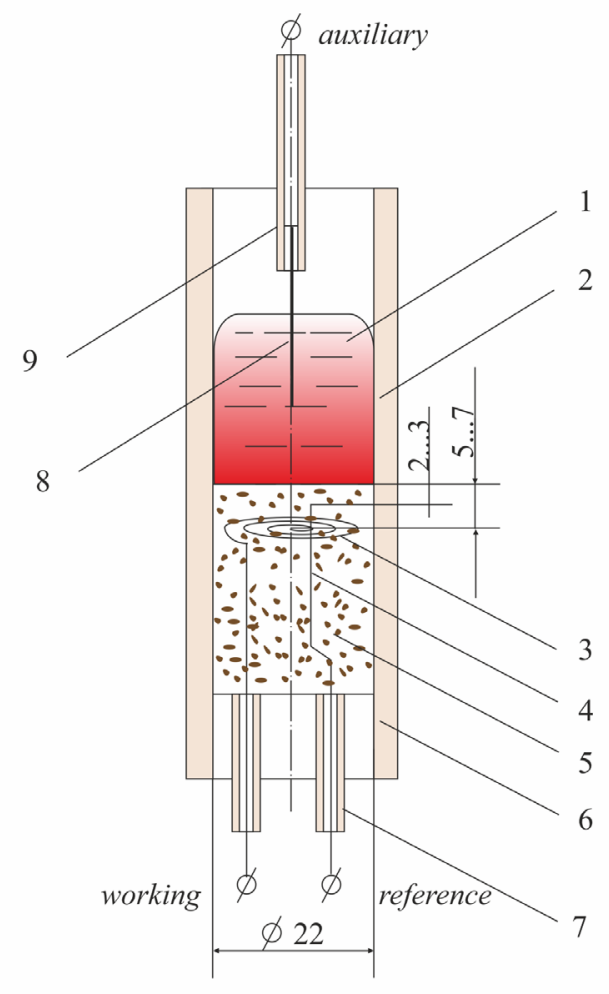

Fig. 5: Cell for studying electrochemical processes in the boundary layer of the lining:

1 - cast iron melt, 2 - alundum cover, 3 platinum working electrode, 4 - platinum reference electrode, 5 - lining made from $\mathrm{SiO}_{2}$ with boric acid, 6 - cork made from $\mathrm{Al}_{2} \mathrm{O}_{3}$, 7 - insulating covers, 8 - platinum auxiliary electrode, 9 - auxiliary electrode insulation contained various complex anions. According to the Esin - Masson theory, this can be explained by the occurrence of the disproportionation reaction:

$$
2 S i_{i} O_{3 i+1-c}^{2(i+1-c)-}=S i_{i-1} O_{3 i-2+c}^{2(i-c)-}+S i_{i+1} O_{3 i+4-c}^{2(i+2-c)-}
$$

Table 3 demonstrates data on the distribution of anions in molten silicates for the values of $\mathrm{N}_{\mathrm{SiO} 2}$, which correspond to $65.6 \% \mathrm{SiO}_{2}$.

It is reasonable to assume that in the boundary layer of the lining, which is softened and glass-like as a result of sintering, the following reaction occurs:

$$
\begin{gathered}
\left\langle S i_{i} O_{3 i+1-c}^{2(i+1-c)-}\right\rangle+\left[2 C^{x+}\right]-4 e=<S i^{4+}> \\
+2 C O+S i_{i-1} O_{(3 i+1-c)-2}^{(i+1-c)-x-4]-}
\end{gathered}
$$

$$
<\mathrm{Si}^{4+}>+4 \mathrm{e}=[\mathrm{Si}]
$$

Contact with the $\mathrm{Fe}-\mathrm{Si}-\mathrm{C}-\mathrm{Mn}$ melt leads to an exchange on the interface and to creation of a double electrical layer. With that, the electrode (metal) and the electrolyte permeate each other, and the anode and cathode stages of the process do not localize on any specific surfaces.

The established electrochemical nature of the crucible reaction gives hope that it is possible to determine the value of protection potential, which is able to inhibit the cathode stage without intensification of the anode stage.

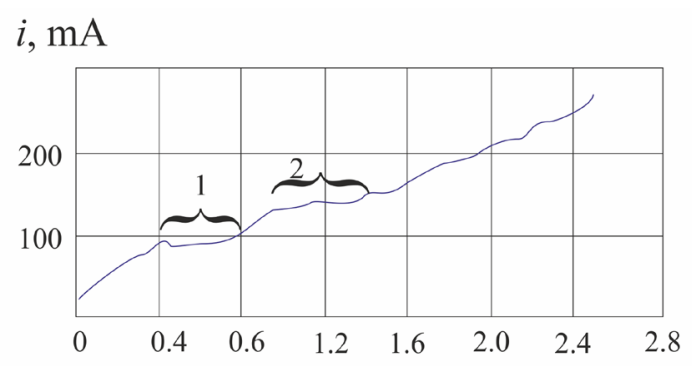

Fig. 6: Potentiodynamic curves (copied from potentiostat diagrams) in reaction conditions 
Assuming that the crucible reaction is composed of electrochemical actions on the cathode and anode, a study of this reaction's electrochemical stages was made, implementing the standard potentiodynamic method at the potentiostat P-5848, with the reference electrode placed in the boundary layer of the lining. The scheme of this cell is shown in Figure 5. The obtained potentiodynamic curves are shown in Figure 6. During $\mathrm{Fe}-3 \% \mathrm{C}$ melting, the potentiodynamic curve clearly shows two horizontal sections corresponding to the limiting currents of the electrode processes: $\mathrm{Si}^{4+}+2 \mathrm{e}=\mathrm{Si}^{2+}$ (section 1 ) and $\mathrm{Si}^{2+}+2 \mathrm{e}=\mathrm{Si}$ (section 2).

It has been established that voltage of 800 $\mathrm{mV}$ is able to inhibit the first stage. The curve that corresponds to the highly siliceous melt (Figure 6) displays certain fluctuations (apparently, caused by impurities) in the area close to the current-zero, which indicates that the reaction is not occurring.

Experimental data has allowed to calculate the empirical values of activation energy and to obtain the expression for determining the protection potential:

$\varepsilon_{3}=\exp \left(\frac{1400}{T}\right)\left[\left(\frac{T}{23205} \ln \frac{P_{C O} \cdot P_{S}}{a_{c} \cdot a_{S O_{3}}}-1.1\right)\right]$

The testing to determine the possibility of protecting the lining from the crucible reaction was carried out in a high-frequency induction furnace. The furnace was simultaneously lined with two alundum crucibles, in one of which the inside lining had a protection voltage. The melt in the crucibles had the same composition. The progress of the reaction was judged by the silicon content in the samples selected at regular time intervals. It has been established, that in the crucible that had no protection voltage, silicon content increased and carbon content decreased faster than in the crucible that had protection voltage. This confirms the influence of electrical current on the process.

\section{CONCLUSION}

The author has clarified the effect of $\mathrm{Mn}$, $\mathrm{S}$, $\mathrm{P}$, elements usually present in cast iron, and of main alloying elements $\mathrm{Cr}, \mathrm{Ni}, \mathrm{Al}, \mathrm{Cu}$ on the $\mathrm{C}$ and Si activity and equilibrium concentrations in cast iron. The corrections of the equilibrium values of $\mathrm{C}$ and Si have been calculated. It has been shown that alloying elements had a substantial impact on the crucible reaction: a significant amount of $\mathrm{Cr}$ inhibited the crucible reaction; the reaction was accelerated by significant amounts of $\mathrm{Ni}, \mathrm{Cu}$, and especially $\mathrm{Al}$. It has been found that the crucible reaction could be accelerated by passing electrical currents of different intensities and polarities. The author demonstrated the possibility to determine the value of protection potential, able to inhibit the cathode stage without intensification of the anode stage: in the crucible that had no protection voltage, silicon content increased and carbon content decreased faster than in the crucible that had protection voltage.

\section{REFERENCES}

1. Dibrov, I. A. Development of the foundry engineering in Russia. Liteishchik Rossii, 2015, 8, 1-48

2. Dibrov, I. A. State and prospects of the Russian foundry production. UNIDO in Russia, Special issue, 2014. Retrieved from http://www.unido-russia.ru/archive/ special_02/special_02_art6/.

3. Elliott, J. F. The Chemistry of Electric Furnace Steelmaking. In Electric Furnace Proceedings. New York: American Institute of Mining, Metallurgical, and Petroleum Enginers, 1974,. 62-74.

4. Esin, O. A. On the calculation of the components' activities of molten silicates. In Proceedings of the Ural Polytechnic Institute (Vol. 2). Sverdlovsk: Ural Polytechnic Institute, 1974,. 2-11

5. Masson, C. R.; Smith, I. B.; Whiteway, S. G. Activities and ionic distributions in liquid silicates: application of polymer theory. Canadian Journal of Chemistry, 1970, 48 (9), 
1456-1464.

6. Masson, C. R. An Approach to the Problem of Ionic Distribution in Liquid Silicates. Proceedings of the Royal Society of London, 1965, A 287, 201-221.

7. Neumann, F.; Dötsch, E. Thermodynamics of $\mathrm{Fe}-\mathrm{C}$-Si melts with particular emphasis on the oxidation behavior of carbon and silicon. Giessereiforschung, 1975, 27 (1), 318-38.

8. Zolotov, Yu. A. Introduction to analytical chemistry. Moscow: BINOM, Laboratoriya Znanii, 2016. 